Jurnal Health Sains: p-ISSN: 2723-4339 e-ISSN: 2548-1398

Vol. 2, No. 6, Juni 2021

\title{
HUBUNGAN SIKAP DENGAN PERILAKU MASYARAKAT TERHADAP PENCEGAHAN COVID 19 DI KECAMATAN KARAWACI TAHUN 2020
}

\section{Ni Nyoman Yeni Pupitasari, Zahra Maulidia Septimar}

Sekolah Tinggi Ilmu Kesehatan (STIKes) YATSI, Tangerang, Banten, Indonesia

Email: aiisyyy01@gmail.com, pangeran_jojoy@yahoo.co.id

\begin{tabular}{ll}
\hline ARTIKEL INFO & ABSTRACT \\
\hline Diterima: 5 Juni 2021 & COVID-19 as a world problem in the health sector. At the \\
Direvisi: 15 Juni 2021 & same time, World Health Organizatin (WHO) said there were \\
Disetujui: 25 Juni 2021 & pneumonia cases in Wuhan, Hubei, China whose cause was \\
\hline Keywords: & unclear and it was increasingly spreading outside the country. \\
community attitudes; & After that, the World Health Organization, in this case the \\
community behavior; COVID & WHO, declared COVID-19 as a pandemic in March 2020. To \\
19 & determine the relationship between attitudes and community \\
& behavior in preventing the transmission of COVID 19 in \\
& Karawaci District, Tangerang City in 2020. This research \\
& method is descriptive analytic. with a cross sectional \\
& approach. Quota sampling technique, research sample of \\
& people living in Karawaci sub-district. Chi-square result. The \\
& relationship between attitude and community behavior is \\
& obtained p-value 0.000 <0.05, which means that there is a \\
& significant relationship between attitude and community \\
& behavior with very low relationship closeness. The results \\
showed that there is a significant relationship between \\
attitudes and community behavior. It is hoped that the \\
community can maintain good attitudes and behavior in \\
preventing transmission of COVID-19.
\end{tabular}

\begin{abstract}
ABSTRAK
COVID-19 sebagai permasalahan dunia di bidang kesehatan. Di waktu yang bersamaan World health Organizatin (WHO) menyebutkan ada kasus pneumonia Wuhan, Hubei, China yang tidak jelas penyebabnya dan semakin menyebar hinnga ke luar negara tersebut. Setelah itu Badan Kesehatan Dunia dalam hal ini WHO menetapkan COVID-19 sebagai pendemik pada bulan Maret 2020. Mengetahui hubungan sikap dengan perilaku masyarakat dalam mencegah penularanCOVID 19 di Kecamatan Karawaci, Kota Tangerang tahun 2020. Metode penelitian ini adalah diskriptif analitik dengan pendekatan cross sectional. Teknik quota sampling, sampel penelitian masyarakat yang tinggal di Kecamatan Karawaci. Hasil chisquare hubungan sikap dengan perilaku masyarakat didapatkan $p$-value $0,000<0,05$ yang artinya ada hubungan yang signifikan sikap dengan perilaku masyarakat dengan keeratan hubungan sangat rendah. Hasil penelitian didapatkan bahwa terdapat hubungan yang bermakna antara sikap dengan perilaku masyarakat. Diharapkan masyarakat
\end{abstract}

Kata Kunci:

$\begin{array}{ll}\text { How to cite: } & \text { Puspitasari, Ni Nyoman Yeni. Zahra Maulidia Septimar (2021) Hubungan Sikap dengan Perilaku } \\ & \text { Masyarakat terhadap Pencegahan Covid 19 di Kecamatan Karawaci Tahun 2020 . Jurnal Health } \\ & \text { Sains 2(6). https://doi.org/10.46799/jhs.v2i6.192 } \\ \text { E-ISSN: } & \text { 2723-6927 } \\ \text { Published by: } & \text { Ridwan Institute }\end{array}$


sikap masyarakat; perilaku dapat mempertahankan sikap dan perilaku yang baik dalam

masyarakat; COVID 19 mencegah penularan COVID-19

\section{Pendahuluan}

Pada akhir tahun 2019, COVID-19 sebagai permasalahan dunia di bidang kesehatan. Di waktu yang bersamaan World Health Organizatin (WHO) menyebutkan ada kasus pneumonia Wuhan, Hubei, China yang tidak jelas penyebabnya dan semakin menyebar hinnga ke luar negara tersebut. Setelah itu Badan Kesehatan Dunia dalam hal ini WHO menetapkan COVID-19 sebagai pendemik pada bulan Maret 2020 (RI, 2020).

Hampir semua Negara di dunia terkena wabah COVID-19 mengingat sangat cepatnya penularan virus ini. Penanganan harus segera di lakukan secepatnya karena peningkatan jumlah kasus semakin hari semakin meningkat. Namun, sampai saat ini belum ada obat yang khusus bagi penderita virus ini. Menurut Badan Kesehatan Dunia di bandingkan China, yang memiliki lebih banyak kasus dan kematian dalam kasus ini adalah Eropa. Data dari WHO Jumlah total kasus virus Corona sampai dengan akhir April 2020, WHO, kini lebih dari 2,8 juta di sedikitnya 213 negara (Gugus Tugas Percepatan Penanganan COVID - 19, 2020).

Kasus pertama COVID-19 di Indonesia terjadi pada tanggal 1 Maret 2020 dengan 2 pasien dari Depok yang terjangkit virus tersebut karena berinteraksi dengan warga Jepang. Virus tersebut juga dengan cepat menyebar diseluruh daerah Indonesia. Berdasarkan data yang diperoleh dari situs resmi Gugus Tugas Percepatan Penanganan COVID-19 per tanggal 19 April 2020 bahwa penderita terus meningkat menjadi 6.760 kasus dengan rincian 5.423 dalam perawatan (80,222\%), sembuh $747(11,05 \%)$, meninggal $590(8,728 \%)$. Ditemukan beberapa kasus dimana petugas kesehatan yang terjangkit virus ini dalam kasus di atas. Sampai saat ini, COVID-19 telah menyebar di 34 Provinsi di
Indonesia, Provinsi DKI Jakarta, Jawa Barat, Jawa Timur, Sulawesi Selatan, Jawa Tengah, dan Banten merupakan 5 provinsi dengan jumlah kasus positif COVID-19 terbanyak (Syaipudin, 2019).

Menjadi 5 terbanyak di Indonesia, di Provinsi Banten pada tanggal 28 April 2020 tedapat 316 kasus, dengan pasien sembuh 52 $(16 \%)$ orang dan yang meninggal $46(14 \%)$ orang. Kota Tangerang menempati urutan pertama terbanyak dari 8 kota/kabupaten pasien positif COVID 19, yaitu dengan kasus 149 orang atau $47 \%$ dari total kasus yang ada di Provinsi Banten. Dengan pasien sembuh sebanyak $30(20 \%)$ orang dan meninggal $20(13 \%)$ orang (Amin \& Samputra, 2021)

Kasus COVID 19 di Kecamatan Karawaci pada tanggal 28 April 2020 pasien positif 5 (3\%) orang, pasien sembuh $4(2,6 \%)$ orang dan meninggal 0 . Dari data tersebut diatas maka dapat disimpulkan di Kecamatan Karawaci masih kecil angka kejadian pesien yang terinfeksi COVID 19. Dari data tersebut diharapkan angka kejadian di Kecamatan Karawaci tidak bertambah dan dapat dikendalikan. Dalam upaya tersebut tentunya peran masyarakat sangatlah penting, terutama sikap dan perilaku masyarakat dalam mecegah penularan COVID 19. Diharapkan masyarakat sebagai garda terdepan dalam pencegahan penularan COVID 19.

Sikap adalah keteraturan perasaan, pikiran perilaku seseorang dalam melakukan interaksi sosial. Menurut para peneliti psikologi sosial, sikap merupakan hal yang penting dalam interaksi sosial, karena sikap mempunyai pengaruh banyak terhadap perilaku dan sebagai isu sentral yang bisa mempengaruhi perilaku seseorang (Sharifah et al., 2018).

Komponen Sikap Menurut (Azwar \& Ridho, 2013), menyimpulkan bahwa sikap 
memiliki 3 komponen utama yang saling berkaitan diantaranya:

\section{Kognitif}

Komponen kognitif adalah gambaran sesuatu yang diyakini oleh seseorang yang mepunyai sikap, komponen ini mengandung keyakinan stereotipe yang dipunyai sesorang tentang sesuatu bisa disamakan dengan penanganan (opini) terutama yang menyangkut isu atau sesuatu kontroversial.

2. Afektif

Komponen ini sering juga disebut komponen emosional, yang didalamnta terdapat perasaan bahagia, sedih, dan terkejut. Komponen afektif bersifat subjektif, persepsi diri yang melibatkan emosional banyak mempengaruhi terbentuknya komponen ini.

3. Konatif

Komponen ini lebih mengarah ke perilaku tertentu sesuai sikap masingmasing seseorang. Komponen konatif berisikan kecenderungan bertindak terhadap sesuatu melalui cara-cara tertentu.

Perilaku adalah hasil dari berbagai pengalaman hubungan imbal balik antara manusia dengan lingkungannya yang berbentuk pengetahuan, sikap ataupun tindakan. Perilaku adalah tanggapan seseorang pada rangsangan dari luar ataupun dari dalam diri sendiri (Notoatmodjo, 2010).

Bentuk - bentuk Perilaku Menurut (Notoatmdojo, 2014). perilaku dibedakan menjadi dua, Dilihat dari bentuk respon terhadap stimulus yaitu :

1. Perilaku tertutup (Convert behavior)

Perilaku ini merupakan tanggapan atas rangsangan yang berupa sifat tertutup (convert). Tanggapan tersebut dibatasi oleh perhatian, persepsi, pengetahuan, kesadaran, dan sikap seseorang yang mendapat rangsangan tersebut, hal tersebut tidak bisa di perhatikan secara detail oleh orang lain.

2. Perilaku terbuka (Overt behavior)

Tanggapan yang di perlihatkan atas stimulus ini bisa dipastikan berupa tindakan ataupun praktik yang nyata dan terbuka, bisa diamati secara detail oleh orang lain.

COVID-19 merupakan virus RNA yang memiliki ukuran partikel 120-160 nm (Wahyuniarti et al., 2021). Virus ini dahulu hanya menginfeksi hewan, antara lain kelelawar dan unta. Sebelum COVID-19 ada dan menyebar di dunia, ada enam macam coronavirus yang bisa menginfeksi manusia, diantaranya alphacoronavirus NL63, alphacoronavirus 229E, betacoronavirus HKU1, betacoronavirus OC43, Middle East Respiratory Syndrome Coronavirus (MERS$\mathrm{CoV})$ dan Severe Acute Respiratory Illness Coronavirus (SARS-CoV), jh.

Menurut PDPI 2020, Infeksi COVID19 memiliki gejala ringan dan sedang sampai dengan berat. Gejala ringan dan sedang antara lain :

1. Demam (sama dengan atau $>38 \mathrm{C}$ ) atau ada riwayat demam, pada kasus tertentu tidak ada demam

2. Batuk/pilek/nyeri tenggorokan.

Sedangkan gejala berat yaitu gejala ringan ditambah dengan:

1. Keluhan sesak nafas (frekuensi nafas $>24 x$ /menit) dan pneumonia berdasarkan gambaran radiologis.

2. Gagal ginjal.

\section{Metode Penelitian}

Metode yang digunakan dalam penelitian ini dengan pendekatan cross sectional survey merupakan sebuah penelitian bertujuan mengetahui dinamika hubungan antara exposure dengan outcome, dengan menggunakan pendekatan, observasi atau pengumpulan data sekaligus pada suatu saat (point time approach). Penelitian dilakukan di 
Kecamatan Karawaci Kota Tangerang pada bulan April - Mei 2020. Populasi dalam penelitian ini adalah masyarakat kecamatan Karawaci kota Tangerang yang berjumlah 180.396 orang (Syaipudin, 2019), sampel dalam penelitian ini sebanyak 399 orang. Teknik pengambilan sampel penelitian dilakukan dengan teknik Sampling berjatah atau quota sampling.

\section{Hasil dan Pembahasan}

\section{A. Hasil Penelitian}

\section{Analisa Univariat}

Responden penelitian ini meliputi penduduk. Kecamatan Karawaci tahun 2020 dengan batasan usia diatas 18 tahun. Dalam penelitian ini responden yang menjadi sample sebanyak 399 orang. Analisa univariat ini bertujuan untuk menggambarkan hasil dari pengambilan data responden meliputi jenis kelamin, umur, pendidikan, sikap masyarakat, dan perilaku masyarakat.

\section{Tabel 1}

\section{Karakteristik Responden}

\section{Berdasarkan Jenis Kelamin, Usia dan} Pendidikan

\begin{tabular}{|c|c|c|c|}
\hline $\mathrm{No}$ & $\begin{array}{l}\text { Karakteristik } \\
\text { Reaponden }\end{array}$ & Frekuensi & $\%$ \\
\hline \multirow{4}{*}{1} & Jenis kelamin & & \\
\hline & Laki Laki & 140 & 35.1 \\
\hline & Perempuan & 259 & 64.9 \\
\hline & Total & 399 & 100 \\
\hline \multirow{5}{*}{2} & Usia & & \\
\hline & $20 \mathrm{~s} / \mathrm{d} 40$ & 336 & 84.2 \\
\hline & $41 \mathrm{~s} / \mathrm{d} 60$ & 56 & 14.1 \\
\hline & Lebih dari 60 & 7 & 1.7 \\
\hline & Total & 399 & 100 \\
\hline \multirow{6}{*}{3} & Pendidikan & & \\
\hline & SMU/SMA & 129 & 32.3 \\
\hline & Diploma & 121 & 30.3 \\
\hline & Sarjana & 136 & 34.1 \\
\hline & Magister/Master & 13 & 3.3 \\
\hline & Total & 300 & 100 \\
\hline & Berdasarkan & tabel & \\
\hline
\end{tabular}

kelamin perempuan yaitu 259 orang $(64,9 \%)$, untuk kategori usia lebih dari setengahnya usia 20 - 40 tahun yaitu 336 orang $(84,2 \%)$ dan untuk kategori pendidikan, responden dengan pendidikan tamatan Sarjana yaitu 136 orang $(34,1 \%)$.

Tabel 2

Distribusi Karakteristik Sikap Masyarakat Kecamatan Karawaci

\begin{tabular}{lcc}
\hline $\begin{array}{c}\text { Karakteristik } \\
\text { Responden }\end{array}$ & Frekuensi & $\%$ \\
\hline Sikap & & \\
\hline Baik & 379 & 95 \\
\hline Kurang Baik & 20 & 5 \\
\hline Total & 399 & 100 \\
\hline
\end{tabular}

Berdasarkan tabel 2 di atas menunjukkan bahwa dari 399 orang mayoritas masyarakat memiliki sikap baik dengan 379 orang (95\%).

Tabel 3

Distribusi Karakteristik Perilaku Masyarakat Kecamatan Karawaci

\begin{tabular}{lcc}
\multicolumn{3}{c}{ Masyarakat Kecamatan Karawaci } \\
\hline $\begin{array}{c}\text { Karakteristik } \\
\text { Responden }\end{array}$ & Frekuensi & $\%$ \\
\hline Perilaku & & \\
\hline Baik & 374 & 93.7 \\
\hline Kurang Baik & 25 & 6.3 \\
\hline Total & 399 & 100 \\
\hline
\end{tabular}

Berdasarkan tabel 3 menunjukkan bahwa dari 399 orang mayoritas masyarakatnya memiliki perilaku baik dengan jumlah sebanyak 374 orang $(93,7 \%)$.

2. Analisa Bivariat

Analisa bivariat dapat dilihat adanya hubungan antara variabel independen (sikap masyarakat) dengan variabel dependen (perilaku masyarakat). Prosedur analisis data dilakukan dengan sesuai denganrencana analisis data yang telah dijadikan pada sebelumnya. 


\section{Tabel 4}

Hubungan Sikap Dengan Perilaku Masyarakat Kecamatan Karawaci

\begin{tabular}{|c|c|c|c|c|c|c|c|}
\hline \multirow{3}{*}{ Sikap } & \multicolumn{4}{|c|}{ Perilaku } & \multirow{2}{*}{\multicolumn{2}{|c|}{ Total }} & \multirow{3}{*}{$\begin{array}{c}\text { p- } \\
\text { value }\end{array}$} \\
\hline & \multicolumn{2}{|c|}{ Baik } & \multicolumn{2}{|c|}{$\begin{array}{c}\text { Kurang } \\
\text { baik }\end{array}$} & & & \\
\hline & $\mathrm{n}$ & $\%$ & $\mathbf{n}$ & $\%$ & $\mathbf{n}$ & $\%$ & \\
\hline Baik & 374 & 98,7 & 5 & 1,3 & 379 & 100 & $\mathbf{0 , 0 0 0}$ \\
\hline $\begin{array}{c}\text { Kurang } \\
\text { Baik }\end{array}$ & 0 & 0 & 20 & 100 & 20 & 100 & \\
\hline Total & 374 & 93,7 & 25 & 6,3 & 399 & 100 & \\
\hline
\end{tabular}

Hasil tabel silang antara sikap dengan perilaku diketahui dari 379 orang yang memiliki sikap baik didapatkan munjukkan perilaku baik sebanyak 374 orang $(98,7 \%)$ dan mimiliki perilaku kurang baik sebanyak 5 orang $(1,3 \%)$, kemudian dari 20 orang yang memiliki sikap kurang baik semuanya perilaku kurang baik. Hasil uji chi square diperoleh nilai $p$ value $0,000(\leq 0,05)$ dengan menggunakan alpha 5\% (0,05) dapat disimpulkan bahwa Ho ditolak yang artinya terdapat hubungan antara sikap dengan perilaku masyarakat dalam pencegahan penularan COVID-19 di Kecamatan Karawaci Kota Tangerang.

\section{B. Pembahasan}

\section{Jenis Kelamin}

Berdasarkan hasil penelitian yang telah dilakukan, sebagian besar responden berjenis kelamin perempuan yaitu sebanyak 259 orang $(64,9 \%)$ kemudian responden laki-laki sebanyak 140 orang (35.1\%). Dari 259 responden perempuan didapatkan 245 permpuan yang berperilaku baik dalampencegahan penularan COVID-19. Jenis kelamin adalah faktor predisposing atau faktor pemudah seseorang untuk berperilaku (Notoatmodjo, 2012). Pada umumnya kaum perempuan lebih rajin dalam menjaga kebersihan dibandingkan dengan kaum laki-laki. Di dalam budaya timur pada kehidupan sehari- hari, Jenis kelamin adalah faktor predisposing atau faktor pemudah seseorang untuk berperilaku (Notoatmodjo, 2012). Pada umumnya kaum perempuan lebih rajin dalam menjaga kebersihan dibandingkan dengan kaum laki-laki. Di dalam budaya timur pada kehidupan sehari- hari, biasanya kaum perempuan diwajibkan untuk menjaga kebersihan dirinya dan lingkungan. Sebagai contohyaitu kaum perempuan biasanya sudah dibiasakan untuk menyapu dengan tujuan menjaga kebersihan lingkungan atau menjaga kebersihan diri dengan gosok gigi hingga rajin memotong kuku guna menjaga penampilan. Hasil ini sesuai dengan hasil penelitian (Ahlina et al., 2016) bahwa perempuan lebih banyak melakukan perilaku pencegahan penyakit degenerative dan menyatakan terdapat hubungan antara jenis kelamin responden dengan perilaku responden dengan $P$-value $0,005<0,05$.

2. Usia

Berdasarkan hasil penelitian yang telah dilakukan, lebih dari sebagian responden berusia $20 \mathrm{~s} / \mathrm{d} 40$ tahun sebanyak 336 orang $(84,2 \%)$, setelah itu usia $41 \mathrm{~s} / \mathrm{d} 60$ tahun sebanyak 56 orang $(14,1 \%)$ dan usia lebih dari 61 sebanyak 7 orang $(1,7 \%)$. Dari responden dengan usia 20 sampe dengan 40 tahun yang sebanyak 336 orang didapatkan mayoritas mempunyai perilaku baik. Penerimaan informasi pada individu yang berusia muda akan lebih mudah untuk dicerna dibandingkan pada usia tua. Individu pada umur dewasa muda jika dilihat dari perkembangan kognitifnya, mereka mempunyai kebiasaan berpikir secara rasional. Mereka biasanya cukup aktif dalam kegiatan diluar rumah, serta jarang mengalami penyakit yang serius 
(Wati \& Ridlo, 2020). Dapat disimpulkan di usia muda mereka dapat dengan cepat menerima informasi dan dan dapat mengolahnya dengan cepat sehingga dapat memengaruhi perilaku seseorang tersebut terutama issue yang sedang aktual saait ini yaitu pentingnya perilaku mencegah penularan COVID 19. Hal ini sejalan dengan hasil penelitian (Wati \& Ridlo, 2020) yang menyatakan bahwa pada usia dewasa mempunyai perilaku baik dalam pencegahan penyakit degeneratif.

3. Pendidikan

Berdasarkan hasil penelitian
yang telah dilakukan, responden
terbanyak dengan pedidikan sarjana
sebanyak 136 orang $(34,1 \%)$, setelahitu
responden dengan pedidikanSMU/SMA
sebanyak 129 orang $(32,3 \%)$, kemudian
responden dengan pendidikan Diploma
dengan jumlah
dengan jumlah

121 orang $(30,3 \%)$ dan dengan pendidikan magister atau master sebanyak 13 orang (3,3\%). Dari 136 orang didapatkan yang mempunyai perilaku baik sebanyak 126 orang.

Pendidikan merupakan suatu usaha pengorganisasian yang dilakukan oleh masyarakat sebagai upaya dalam meningkatkan derajat kesehatan. Tingkat pendidikan bisa berpengaruh pada PHBS dalam rumah tangga atau keluarga. Tingkat pendidikan yang kurang menyebabkan rendahnya kesadaran seseorang akan pentingnya kebersihan lingkungan. Apabila seseorang mempunyai pendidikan formal yang baik, maka kesadarandalam menjaga kesehatan lingkungantermasuk pemahamannya mengenai penerapan prinsip-prinsip PHBS juga semakin baik. Pendidikan merupakan serangkaian proses dalam membentuk perilaku pada individu (Al-Mubarak et al., 2007).
Tingginya pendidikan yang dimiliki oleh seseorang dapat mempermudah individu tersebut dalam menerima informasi terutamamengenai kesehatan. Sebaliknya, dengan tingkat pendidikan yang rendah, akan menjadikan seseorang mengalami hambatan dalam menerima informasi baik seputar kesehatan ataupun lainnya. Hasil penelitian yang dilakukan di Surakarta, yang menjelaskan terdapat pengaruh antara pendidikan terhadap PHBS. Dengan tingginya tingkat pendidikan yang dimiliki, akan mudah untuk orang itu menerima konsep hidup yang sehat secara mandiri, kreatif, dan berkesinambungan (Wati \& Ridlo, 2020). Hal ini sejalan dengan hasil penelitian (Putri \& Naftassa, 2017), menyatakan bahwa pendidikan tinggi memeliki perilaku baik dalam mencegah penularan penyakit dan tingkat pendidikan mempengaruhi perilaku masyarakat dalam pencegahan penyakit, dengan nilai $P$-value 0,003 $(<0,05)$

4. Sikap Masyarakat

Berdasarkan hasil penelitian ini didapatkan sebagian besar sikap masyarakat baik dengan jumlah 379 orang (95\%) dan masyarakat yang memiliki sikap kurang baik sebanyak 20 orang $(5 \%)$. sikap merupakan domain terpenting dalam membentuk suatu perilaku pada seseorang. Sikap adalah suatu hal yang memiliki kecenderungan dalam memberikan respon, baik respon positif maupun negatif terhadap orang, objek ataupun pada situasi tertentu. Sikap dengan perilaku tidaklah sama dan perilaku sendiri juga tidaklah selalu menunjukkan sikap seseorang. Seseorang seringkali bisa menunjukkan perubahan pada tindakan yang 
berlawanan dengan sikapnya. Sikap seseorang dapat berubah ketika mereka mendapatkan tambahan informasi mengenai suatu objek tertentu (Notoatmodjo, 2010).

5. Perilaku Masyarakat

Berdasarkan hasil penelitian ini didapatkan sebagian besar perilaku masyarakat baik dengan jumlah 374 orang $(93,7 \%)$ dan masyarakat yang memiliki perilaku kurang baiksebanyak 25 orang $(6,3 \%)$. Dalam penelitian ini sebagian besar responden memiliki perilaku baik dalam pencagahan COVID 19 di Kecamatan Karawaci. Hal ini selaras dengan angka kejadian COVID di Kecamatan Karawaci yang pada bulan April yaitu hanya 3 orang $(5 \%)$ atau dapat diartikan mayoritas responden memiliki perilaku baik dalam pencegahan penularan COVID 19 sihingga dapat menekan angka kejadian orang yang terjangkit COVID 19 di Kecanmatan Karawaci. Perilaku adalah keteraturan tertentu dalam hal perasaan (afeksi), pemikiran (kognisi), dan predisposisi tindakan (konasi) seseorang terhadap suatu aspek di lingkungan sekitarnya (Irwan \& Wicaksono, 2017).

6. Hubungan Sikap dengan Perilaku Masyarakat dalam Pencagahan Penularan COVID 19 di Kecamatn Karawaci

Berdasarkan hasil penelitian ini didapatkan masyarakat yang memiliki sikap baik dengan perilakuu baik sebanyak 374 orang $(98,7 \%)$ dan masyarakat yang meiliki sikap baik dengan perilaku kurang baik sebanyak5 orang $(1,3 \%)$. Kemudian masyarakat yang memiliki sikap kurang baik dengan perilaku baik tdak ada dan masyarakat yang memiliki sikap kurang baik dengan perilaku kurang baik sebanyak 20 orang (100\%).Dengan nilai $P$-value $0,000(<0,05)$ sehingga $\mathrm{H} 0$ ditolak dan $\mathrm{Ha}$ gagal ditolak, dapat diartikan terdapat hubungan antara sikap dan perilaku dalam pencegahan penularan COVID- 19.

Sikap memiliki tiga komponen yang mendukung yaitu komponen kognitif, afektif, dan konatif. Komponen kognitif yang merupakan suatu representasi mengenai sesuatu yang menjadi kepercayaan pada diri individu yang memiliki suatu sikap. Komponen afektif yaitu suatu rasa di dalamnya meliputi aspek emosional. Komponen konatif juga sebagai suatu aspek yang memiliki kecenderungan untuk berperilaku sesuai dengan sikap yang di punyai pada diri seseorang tersebut (Azwar \& Ridho, 2013).

Sikap sendiri memiliki fungsi yang dibagi atas empat fungsi. Fungsi pertama, sikap digunakan sebagai alat untuk menyesuaikan diri dimana sikap itu bersifat communicable yang berati merupakan sesuatu yang mudahberjalan sehingga kemungkinan bisa menjadi milik bersama. Kedua, sikapmerupakan alat yang mengatur perilaku, seseorang mengetahui bahwa pola kebiasaan anak kecil pada umumnya merupakan bentuk reaksialami terhadap barang yang ada disekitarnya. Diantara bentuk suatu rangsangan dan juga reaksi tidak mempunyai sebuah pertimbangan. Tetapi pada orang dewasa yang mempunyai usia sudah matang, bentuk rangsangan itu umumnya tidak diberi reaksi secara langsung melainkan cerminan dari adanya proses secara sadar dalam melakukan penilaian terhadap perangsangan itu. Ketiga, digunakan sebagai alat untuk mengatur pengalaman-pengalaman, yang 
diartikan sebagai manusia didalam menerima suatu pengalaman dari lingkungan eksternal maka sikapnya tidak pasif akan tetapi menerimanya secara aktif. Ini berarti bahwa pengalaman yang semuanya berasaldari faktor eksternal tidaklah semuanya dilaksanakan oleh seseorang tetapi orang juga menentukan mana yang sekiranya akan dia lakukan dan yang tidak dilakukannya. Keempat, sikap sebagai wujud pernyataan kepribadian seseorang, yang mana sikap sering menunjukkan suatu kepribadian pada diri individu (Wati \& Ridlo, 2020).

Hal ini sejalan dengan hasil penelitian (Iswanto, 2021) yang menyatakan terdapat hubungan antara sikap dengan perilaku dalam pencegahan penyakit filariasis dengan P-value 0,000 $(<0,05)$. Penelitian oleh (Putri \& Naftassa, 2017) juga mendapatkan hasil yang sama, terdapat hubungan antara sikap dan perilaku pencegahan penyakit degenerative dengan nilai $\mathrm{P}$-value $0,018 \quad(<0,05)$. Dalam penilitian menyatakan hal yang serupa yaitu terdapat hubungan bermakna antara sikap terhadap perilaku upaya pencegahan penyakit malaria di Puskemas Koni Kota Jambi dengan nilai $p$-value 0,000 .

\section{Kesimpulan}

Berdasarkan pembahasan dari hasil penelitian mengenai hubungan sikap dengan perilaku masyarakat terhadap pencegahan penularan COVID-19 di Kecamatan Karawaci periode April-Mei 2020, maka dapat disimpulkan Terdapat hubungan antara hubungan sikap dengan perilaku masyarakat terhadap pencegahan penularan COVID-19 di Kecamatan Karawaci. dengan nilai p $0,000<\alpha$ $(0,05)$.

\section{BIBLIOGRAFI}

Ahlina, S., Husodo, B. T., \& Istiarti, V. G. T. (2016). Faktor Yang Berhubungan Dengan Perilaku Pencegahan Penyakit Degeneratif Pada Pasien Rawat Inap Rumah Sakit Islam Sultan Agung Kota Semarang. Jurnal Kesehatan Masyarakat (E-Journal), 4(3), 10891095. Google Scholar

Al-Mubarak, S., Al-Ali, N., Abou Rass, M., Al-Sohail, A., Robert, A., Al-Zoman, K., Al-Suwyed, A., \& Ciancio, S. (2007). Evaluation Of Dental Extractions, Suturing And Inr On Postoperative Bleeding Of Patients Maintained On Oral Anticoagulant Therapy. British Dental Journal, 203(7), E15-E15. Google Scholar

Amin, M., \& Samputra, P. L. (2021). The Art Of Social Work Practices In Indonesia The Impact Of Lssr Policy On The SocioEconomic Sector In Banten Province. Jurnal Ilmu Sosial Mamangan, 10(1), 40-53. Google Scholar

Azwar, S., \& Ridho, A. (2013). Abilitas Komposit Dalam Tes Potensi. Jurnal Psikologi, 40(2), 127-142. Google Scholar

Irwan, A. W., \& Wicaksono, F. Y. (2017). Perbandingan Pengukuran Luas Daun Kedelai Dengan Metode Gravimetri, Regresi Dan Scanner. Kultivasi, 16(3). Google Scholar

Iswanto, A. H. (2021). Impact Of Lean Six Sigma At Pharmacy Unit On Hospital Profitability Before And During Covid19 Pandemic. International Journal of Lean Six Sigma. Google Scholar

Notoatmdojo. (2014). Metodelogi Penelitian Kesehatan. Jakarta; Rineka Cipta. Google Scholar

Notoatmodjo, S. (2010). Ilmu Perilaku Kesehatan. Penerbit Rineka Cipta. Google Scholar 
Hubungan Sikap dengan Perilaku Masyarakat terhadap Pencegahan Covid 19 di Kecamatan

Karawaci Tahun 2020

Notoatmodjo, S. (2012). MetodologiPenelitian Kesehatan. Google Scholar

Putri, R., \& Naftassa, Z. (2017). Hubungan Tingkat Pendidikan Dan Pengetahuan Masyarakat Dengan Perilaku Pencegahan Demam Berdarah DengueDi Desa Kemiri, Kecamatan Jayakerta, Karawang Tahun 2016. Magna Medica: Berkala Ilmiah Kedokteran Dan Kesehatan, 1(4), 1-7. Google Scholar

Ri, K. (2020). Pedoman Pencegahan Dan Pengendalian Coronavirus Disease (Covid-19)'. Kemenkes Ri, 0-115. Google Scholar

Sharifah, N., Nur, A., \& Sarva, M. P. (2018). The Used Of Dragon Fruit Peels As EcoFriendly Wastewater Coagulants. Asian Journal Of Agriculture And Biology, Special Issue, 66-71. GoogleScholar

Syaipudin, L. (2019). Efektifitas Media Komunikasi Di Tengah Pandemi: Respon Gugus Tugas Percepatan Penanganan Covid-19 Kabupaten Tulungagung. Kalijaga Journal of Communication, 1(2), 165-178. Google Scholar
Wahyuniarti, D. R., Haqiki, F., Wibisono, B., Syahreza, R., Al-Mahdy, F. J., Sutinnah, S., Rihansyah, M. R., Andriana, A., Zain, M. H. K., \& Pulungan, A. S. (2021). Bersama Bersinergi Melawan Covid-19. Prosiding Seminar Nasional Pengabdian Masyarakat Lppm Umj, 1(1). Google Scholar

Wati, P. D. C. A., \& Ridlo, I. A. (2020). Perilaku Hidup Bersih Dan Sehat Pada Masyarakat Di Kelurahan Rangkah Kota Surabaya. Jurnal Promkes: The Indonesian Journal of Health Promotion And Health Education, 8(1), 47-58. Google Scholar

\section{Copyright holder:}

Ni Nyoman Yeni Pupitasari, Zahra Maulidia Septimar (2021)

First publication right:

Jurnal Health Sains

This article is licensed under: 